\title{
DAUR ULANG KARTON BEKAS MENJADI PRODUK BERNILAI
}

\author{
Popy Yuliarty ${ }^{1}$,Rini Anggraini ${ }^{2}$, Retna Kristiana $^{3}$ \\ 1 Prodi Teknik Industri, Universitas Mercu Buana, jl.Meruya Selatan No.1 Kembangan Jakbar \\ 2 Prodi Teknik Mesin, Universitas Mercu Buana, jl.Meruya Selatan No.1 Kembangan Jakbar \\ 3 Prodi Teknik Sipil, Universitas Mercu Buana, jl.Meruya Selatan No.1 Kembangan Jakbar \\ popy.yuliarty@mercubuana.ac.id
}

\begin{abstract}
Abstrak. Daur ulang adalah proses untuk menjadikan suatu bahan bekas menjadi bahan baru dengan tujuan mencegah adanya sampah yang sebenarnya dapat menjadi sesuatu yang berguna, mengurangi penggunaan bahan baku yang baru, mengurangi penggunaan energi, mengurangi polusi dan emisi gas rumah kaca jika dibandingkan dengan proses pembuatan barang baru. Pada kegiatan ini, sampah difokuskan kepada sampah karton bekas tempat nasi (box nasi), bekas box susu, bekas box pasta gigi dan lain-lain, atau dengan kata lain termasuk dalam jenis karton duplek dengan ketebalan bebas. Evaluasi pelaksanaan kegiatan pengabdian masyarakat ini dilakukan dengan cara penyebaran kuisiober kepada peserta yang berjumlah 18 orang. Tujuan dari kuisioner ini adalah untuk mengevaluasi sejauh mana keberhasilan kegiatan. Berdasarkan nilai rata-rata di atas dapat disimpulkan bahwa secara umum, kegiatan ini dapat dikatagorikan berhasil, peserta antusias mempelajari dan mempraktekkan materi pelatihan. Namun waktu pelaksanaannya kurang lama sehingga mereka minta waktu selanjutnya untuk belajar lagi (pertanyaan nomer 4) karena isi/materi pelatihan dirasa cukup sulit
\end{abstract}

Kata kunci : daur ulang, karton bekas,produk bernilai

\section{PENDAHULUAN}

Daur ulang adalah proses untuk menjadikan suatu bahan bekas menjadi bahan baru dengan tujuan mencegah adanya sampah yang sebenarnya dapat menjadi sesuatu yang berguna, mengurangi penggunaan bahan baku yang baru, mengurangi penggunaan energi, mengurangi polusi dan emisi gas rumah kaca jika dibandingkan dengan proses pembuatan barang baru (Wikipedia).

Daur ulang adalah salah satu strategi pengelolaan sampah padat yang terdiri atas pemilahan, pengumpulan, pemrosesan, pendistribusian dan pembuatan produk/material bekas pakai, dan komponen utama dalam manajemen sampah modern dan bagian ke tiga dalam proses hierarkhi sampah $4 \mathrm{R}$ (reduce, reuse,recycle and replace). Material yang bisa di daur ulang bisa terdisi dari sampah kaca, plastik, kertas, logam, tekstil dan barang elektronik. Serinkali kita menganggap remeh sampah ini, namun ternyata dapat diolah menjadi produk bernilai (Wikipedia).
Pada kegiatan ini, sampah difokuskan kepada sampah karton bekas tempat nasi (box nasi), bekas box susu, bekas box pasta gigi dan lainlain, atau dengan kata lain termasuk dalam jenis karton duplek dengan ketebalan bebas. Sampah ini dapat dengan mudah ditemukan disekitar kita, misalnya disekitar kampus dan dilingkungan rumah tangga dan sebagainya. Sayang jika dibuang, bila dibakar juga dapat menyebabkan polusi udara. Dari sampah ini, muncullah ide untuk memanfaatkannya menjadi produk berharga. Gambar 1. di bawah ini adalah contoh-contoh karton box bekas yang bisa didaur ulang

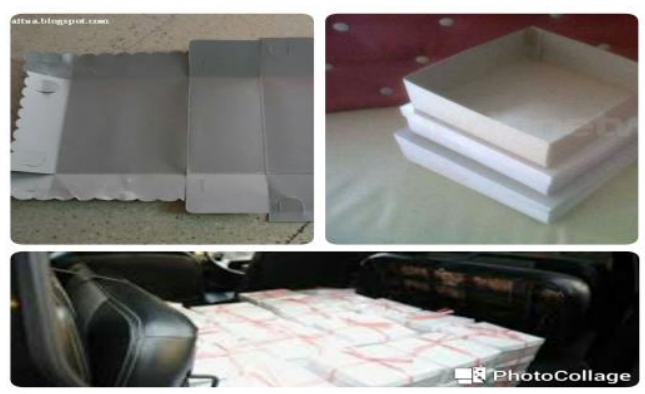


Gambar 1.Contoh karton box bekas yang bisa didaur ulang

Bekas box nasi dll tersebut nantiya akan dibuat vas bunga dll. Gambar 2. di bawah ini adalah contoh bentuk produk hasil daur ulang sampah box.
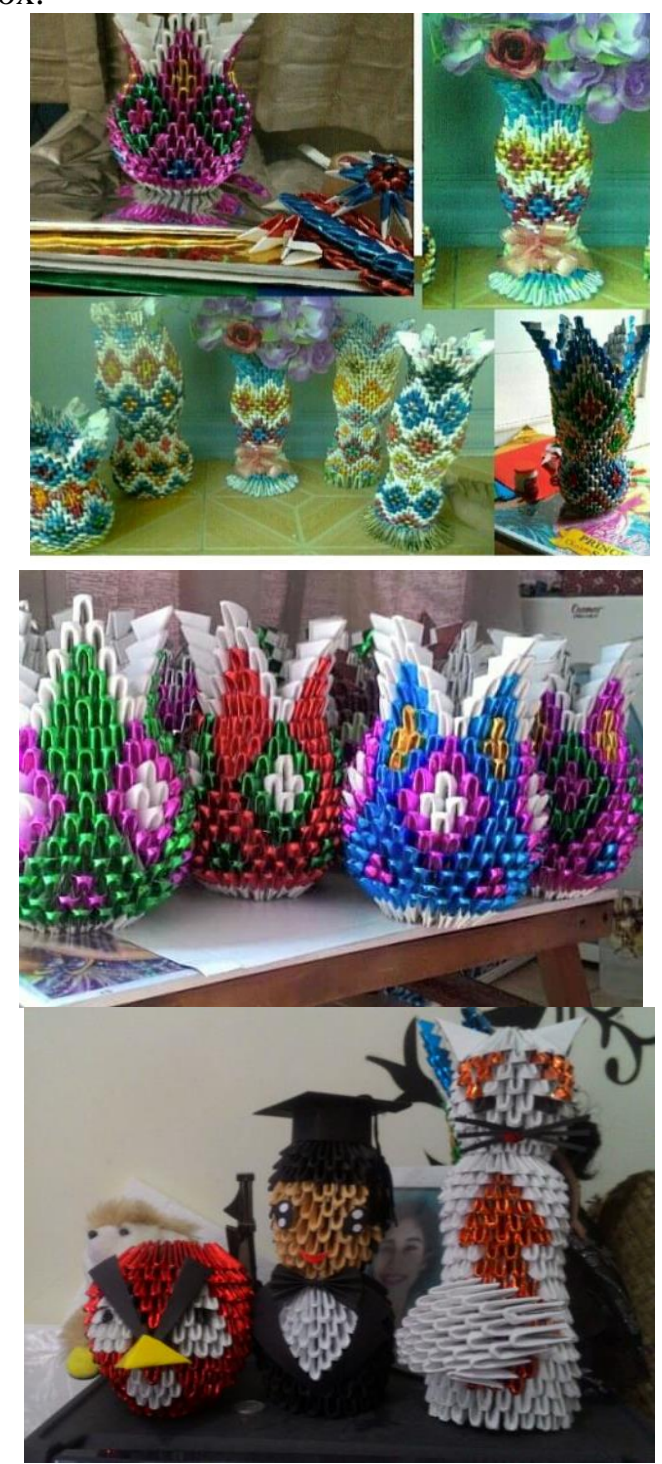

Gambar 2. Contoh produk hasil daur ulang karton bekas

Pelatihan mendaur ulang sampah karton ini nantinya diharapkan akan dapat memberikan nilai tambah bagi para peserta serta yang lebih penting lagi adalah memenfaatkan sampah menjadi produk bernilai. Konsep yang digunakan untuk membuat produk adalah konsep origami. Produk yang dihasilkan pastinya akan memmpunyai niai seni serta nilai ekonomis yaiytu produk yang dapat dijual.

\section{Permasalahan Mitra}

Pelatihan ini merupakan pelatihan daur ulang sampah karton.. Calon peserta pada pelatihan ini adalah para ibu PKK yang berdomisili di sekitar RPTRA Mahkota Kembangan Meruya Selayan.

Permasalahan yang tampak jelas yaitu banyaknya sampah bekas karton disekitar kita, lalu muncullah ide untuk merubahnya menjadi produk bernilai serta permasalahan ketidaktahuan masyarakat (dalam hal ini objeknya adalah para ibu rumah tangga) untuk mengolahnya sehingga bisanya dibuang begitu saja di tempat sampah atau berakhir di tukang rongsokan. Karena untuk merubah sampah menjadi bernilai memerlukan pengetahuan dan keahliah khsus, yang belum tentu bisa dipelajari sendiri oeh tiap individu, maka kegiatan pelatihan semacam ini dirasakan sangat bermanfaat.

\section{Target}

Target dalam pelatihan ini adalah para ibu rumah tangga yang kesehariannya berada di rumah atau bukan wanita karier, dengan pelatihan ini diharapkan mereka mampu mempraktekannya sendiri di kehidupannya sehari-hari, dengan keterampilan ini diharapkan mereka dapat ikut berkontribusi mengurangi sampah karton, mendaur ulang menjadi produk yang bernilai, baik nilai seni maupun nilai ekonomis.

\section{MEODE PELAKSANAAN}

\section{Sifat dan Bentuk Kegiatan}

Pelatihan mendaur ulang sampah karton menjadi produk bernilai ini bersifat terbuka untuk para ibu rumah tangga dan para remaja, khususnya di Kota Tangerang. Bentuk metode penyampaiannya adalah pemberian materi dan praktek secara langsung. Bentuk produk yang akan di buat pertama diberikan oleh pelatih, selanjutnya peserta di mengikuti instruksi pelatih. Peserta juga diberikan informasi mengenai teknik pmbuatan dan alat-alat yang diperlukan untuk membuat bentuk. Selain itu, para peserta pelatihan akan diberika wawasan mengenai manfaat mendaur ulang sampah karton,serta ide=ide lain untuk jenis sampah lain. 


\section{Kuisioner}

Kuesioner adalah suatu teknik pengumpulan informasi yang memungkinkan analis mempelajari sikap-sikap, keyakinan, perilaku, dan karakteristik beberapa orang utama di dalam organisasi yang bisa terpengaruh oleh sistem yang diajukan atau oleh sistem yang sudah ada. Dengan menggunakan kuesioner, analis berupaya mengukur apa yang ditemukan dalam wawancara, selain itu juga untuk menentukan seberapa luas atau terbatasnya sentimen yang diekspresikan dalam suatu wawancara.

Penggunaan kuesioner tepat bila :

1. Responden (orang yang merenpons atau menjawab pertanyaan) saling berjauhan

2. Melibatkan sejumlah orang di dalam proyek sistem, dan berguna bila mengetahui berapa proporsi suatu kelompok tertentu yang menyetujui atau tidak menyetujui suatu fitur khusu dari sistem yang diajukan.

3. Melakukan studi untuk mengetahui sesuatu dan ingin mencari seluruh pendapat sebelum proyek sistem diberi petunjuk-petunjuk tertentu.

4. Ingin yakin bahwa masalah-masalah dalam sistem yang ada bisa diidentifikasi dan dibicarakan dalam wawancara tindak lanjut.

Kuisioner yang akan disebarkan kepada respondennya (dalam hal ini adalah peserta pelatihan) ditujukan untuk mencari tahu tentang segala sesuatunya mengenai kegiatan yang telah mereka ikuti.

\section{Prosedur Kerja}

Konsep yang digunakan adalah teknik melipat kertas atau yang disebut origami. Origami, Ori berarti "lipat" dan Kami berarti "kertas" dalam bahasa Jepang merupakan seni melipat, bahan yang biasa digunakan adalah kertas atau kain yang biasanya berbentuk persegi. Hasil origami merupakan hasil kerja tangan yang sangat teliti dan unik.

Langkah-Langkah prosedur kerja pelatihan daur ulang sampah karton ini sebagai berikut : Bahan-Bahan yang di butuhkan

1. Material yang digunakan adalah karton bekas yang agak tebal (bekas box nsi, box susu, box pasta gigi dll)
2. kertas warna warni, kertas kado dll

3. Karet

4. Lem kertas (mengunakan lem Fox)

5. Double tape

Cara Pembuatan :

1. Potong-potong karton menjadi ukuran 3 $\mathrm{cm}$ x $10 \mathrm{~cm}$ sebanyak mungkin

2. Poptong kertas warna warni sesuai selera, dengan ukuran 1/3 dari karton no. 1

3. Tempel kertas warna warni pada setiap lembar karton yang telah dipotong.

4. Lipat sesuai instruksi

5. Lakukan penyusunan sesuai bentuk yang akan dibuat (vas bunga, lampu dll)

Berikut ini adalah contoh bentuk-bentuk handuk yang bisa di buat dengan tidak menutup kemungkinan untuk bentuk lain.

\section{HASIL DAN PEMBAHASAN}

Utuk mengawali kegiatan pengebdian masyarakat ini, maka team pelaksana langsung berkoordinasi dengan sasaran pengabdian masyarakat ini yaitu langsung datang mengunjungi ke lokasi RPTRA Mahkota Kembangan Jakarta Barat yang berjarak sekitar 2,6 km dari kampus Universitas Mercubuana Meruya Jaarta Barat.

Team pelaksaa menemui Koordinator RPTRA Mahkota yaitu ibu Kunhidayati. Dari petemuan ini kami menyepakati akan mencari waktu pelaksanaan kegiatan serta tekhnis kegiatan yang akan dilaksanakan. Dari beliau, kami mendapat informasi bahwa peserta kebanyakan ibu-ibu PKK serta penduduk sekitar yang berjumlah kurang lebih 15 orang.Dokumentasi tahap awal kegiatan pengabdian masyarakat ini dapat dilihat pada Gambar 4

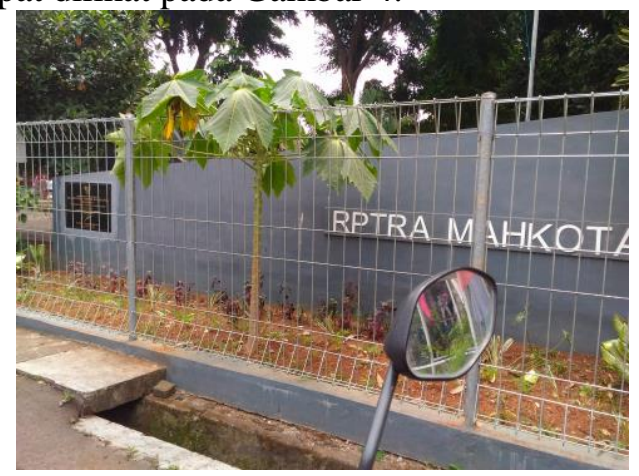

Gambar 4. Foto lokasi kegiatan RPTRA Mahkota Jakarta Barat Sumber : Dokumentasi RPTRA Mahkota 

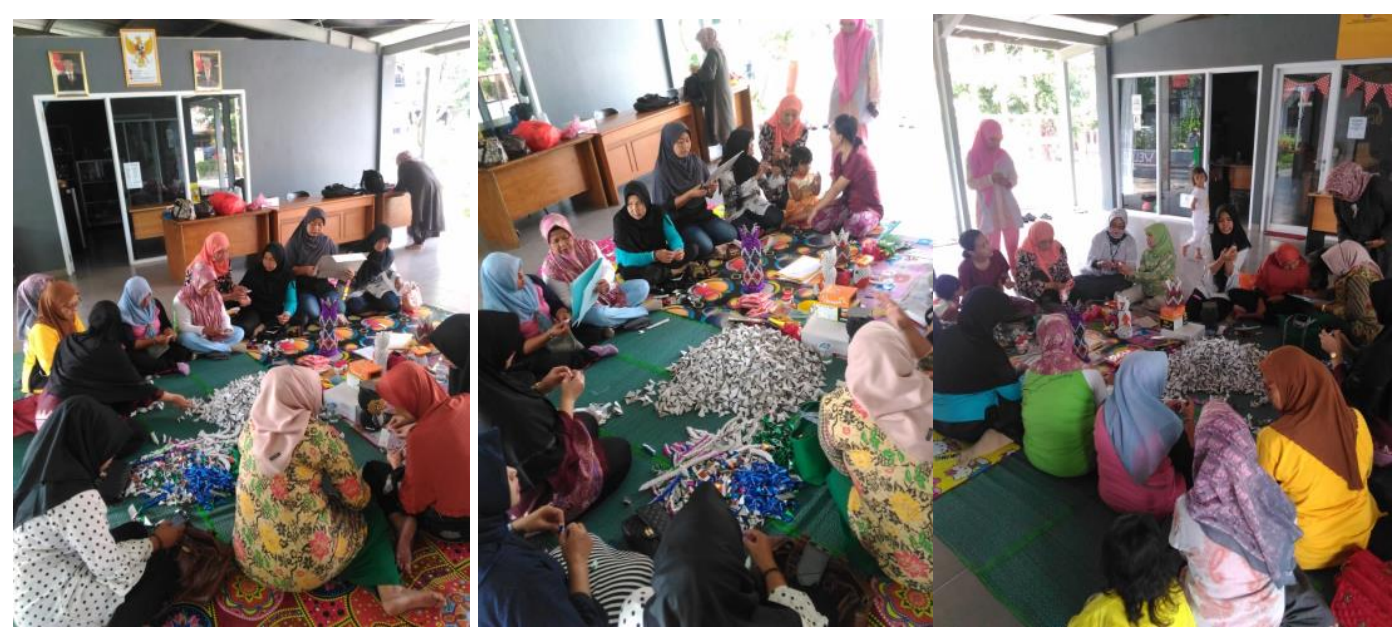

Gambar 5. Dokumentasi Kegiatan

\section{Evaluasi Kegiatan}

Evaluasi pelaksanaan kegiatan pengabdian masyarakat ini dilakukan dengan cara penyebaran kuisiober kepada peserta yang berjumlah 18 orang. Tujuan dari kuisioner ini adalah untuk mengevaluasi sejauh mana keberhasilan kegiatan. Hasil rekapitulasi penilaia peserta terhadap tiap kriteria penilaian dapat dilihat pada Tabel 1. di bawah ini :

Tabel 1. Rekapitulasi Kuisioner Evaluasi Kegiatan

\begin{tabular}{|l|l|c|}
\hline No. & \multicolumn{1}{|c|}{ Kriteria yang dinilai } & Rata-rata \\
\hline 1. & Kondisi tempat pelaksanaan kegiatan & 4 \\
\hline 2 & Jarak tempat pelaksanaan dengan kediaman peserta & 4 \\
\hline 3. & Waktu pelaksanaan kegiatan & 3,22 \\
\hline 4. & Lamanya waktu pelaksanaan kegiatan & 3 \\
\hline 5. & Luas ruangan tempat pelatihan & 4 \\
\hline 6. & Ketersediaan alat dan bahan & 4 \\
\hline 7. & Penjelasan instruktur tentang cara membuat bentuk hantaran & 3,44 \\
\hline 8. & Instruktur memotivasi peserta untuk berkreasi sendiri & 3,33 \\
\hline 9. & $\begin{array}{l}\text { Kesediaan instruktur untuk memberi petunjuk bagi peserta yang } \\
\text { belum selesai }\end{array}$ & 4 \\
\hline 10. & Isi / materi pelatihan & 3,05 \\
\hline 11. & Manfaat pelatihan bagi peserta & 4 \\
\hline 12. & Konsumsi bagi peserta & 4 \\
\hline
\end{tabular}

Berdasarkan nilai rata-rata di atas dapat disimpulkan bahwa secara umum, kegiatan ini dapat dikatagorikan berhasil, peserta antusias mempelajari dan mempraktekkan materi pelatihan. Namun waktu pelaksanaannya kurang lama sehingga mereka minta waktu selanjutnya untuk belajar lagi (pertanyaan nomer 4) karena isi/materi pelatihan dirasa cukup sulit.

\section{KESIMPULAN}

Kesimpulan yang bisa diambil dari kegiatan pengabdian pada masyarakat ini adalah ;

1. Tidak hanya melaksanakan kegiatan, team juga melakukan evalusai untuk 
mengahui sejauh mana keberhasilan dari kegiatan ini. Alat untuk ecaluasi menggunakan kuisioner yang disebarkan dan diisi langsung oleh peserta kegiatan.

\section{SARAN}

Berdasarkan dari urut-urutan kegiatan sampai pada penyelesaian kegiatan, maka saran yang dapat kami brikan yaitu :

1. Kegiatan pengabdian masyarakat seperti ini mendapatkan tanggapan positif dari Ibu Ketua PKK serta masyarakat sekitrnya yang tergabung dalam Ibu-ibu PKK dan masyarakat umum, maka harus terus dikembangkan secara berkelompok dan terprogram.

2. Perlu ada kegiatan lanjutan yang terorganisir untuk melihat dampaknya kepada peserta pelatihan, baik positif maupun negatif untuk menjadi pembelajaran bagi pelaksana.
3. Pihak RPTRA Mahkota mengharapkan ada pelatihan lebuh lanjut berupa keterampilan dasar seperti pelatihan membuat pakaian.

\section{DAFTAR PUSTAKA}

[1] Djoko Santoso, 2013, Kewirausahaan modul pembelajaran, Direktorat Jendral Pembelajaran dan Kemahasiswaan Ditjen Pendidikan Tinggi Kementerian Pendidikan dan Kebudayaan, Jakarta

[2] Suharyadi, Arissetyanto Nugroho, Purwanto, SK., dan Mamam Faturohman, 2007, Kewirausahaan: Membangun Usaha Sukses Sejak Usia Dini, Salemba Empat dan Universitas Mercu Buana, Jakarta

[3] www.indonetwork.co.id

[4] http://id.m.wikipedia.org 